\title{
Sistem Inferensi Fuzzy Untuk Prediksi Sindrom Metabolik Bagi Penyandang Penyakit Ginjal Kronik
}

\author{
Muhammad Zainudin Al Amin*1, Sri Kusumadewi², Linda Rosita ${ }^{3}$ \\ ${ }^{1}$ Mahasiswa Magister Informatika, Fakultas Teknologi Industri, Universitas Islam Indonesia, \\ Yogyakarta \\ ${ }^{2}$ Departemen Informatika, Fakultas Teknologi Industri, Universitas Islam Indonesia, Yogyakarta \\ ${ }^{3}$ Departemen Patologi Klinik, Fakultas Kedokteran, Universitas Islam Indonesia, Yogyakarta \\ e-mail: *11 muhammad.amin@students.uii.ac.id, ${ }^{2}$ sri.kusumadewi@uii.ac.id, \\ ${ }^{3}$ linda.rosita@uii.ac.id
}

\begin{abstract}
Abstrak
Penderita Penyakit Ginjal Kronik(PGK) meningkat setiap tahunnya. Salah satu faktor resikonya akibat sindrom metabolik karena komponen pada sindrom metabolik merupakan penyebab dari faktor resiko PGK. Tujuan penelitian ini yaitu membangun sistem inferensi fuzzy untuk memprediksi sindrom metabolik bagi penyandang PGK. Metode pada penelitian ini melalui studi pustaka dalam membangun aturan fuzzy dan pembentukan sistem inferensi fuzzy. Variabel yang digunakan yaitu indeks massa tubuh, tekanan darah, trigliserida, HDL dan gula darah puasa. Pengujian sistem dilakukan pada delapan data pasien hemodialisis. Hasil pengujian sistem tersebut mampu memberikan informasi terkait persentase tingkat risiko sindrom metabolik pada 7 pasien penyakit ginjal kronik.
\end{abstract}

Kata kunci—Penyakit Ginjal Kronik, Sindrom Metabolik, Sistem Inferensi Fuzzy

\begin{abstract}
Patients with Chronic Kidney Disease (CKD) are increasing every year. One of the risk factors is due to metabolic syndrome because components in the metabolic syndrome are the cause of risk factors for CKD. The purpose of this study is to build a fuzzy inference system to predict metabolic syndrome for people with CKD. The method in this research is through literature study in building fuzzy rules and forming a fuzzy inference system. The variables used are body mass index, blood pressure, triglycerides, HDL and fasting blood sugar. System testing was carried out on eight hemodialysis patient data. The results of the system test are able to provide information related to the percentage of metabolic syndrome risk levels in 7 patients with chronic kidney disease.
\end{abstract}

Keywords — Chronic Kidney Disease, Metabolic Syndrome, Fuzzy Inference System

\section{PENDAHULUAN}

$\mathrm{I}^{\mathrm{n}}$ novasi teknologi di abad ke-21 sangat mendukung dan berkembang cukup pesat terutama dalam bidang kedokteran dan pelayanan kesehatan. Kemajuan terbaru dalam teknologi kesehatan telah menyediakan berbagai macam diagnostik, terapi, dan alat instrument rehabilitasi. Berbagai macam aplikasi terutama untuk membantu dalam diagnosis awal penyakit tertentu juga telah banyak bermunculan sebagai bentuk inovasi teknologi terbaru.

Peran media elektronik sangat membantu dalam memberikan informasi terbaru yang berkaitan dengan tren penyakit yang bermunculan di era perkembangan teknologi. Salah satu 
contohnya yaitu informasi terkait prevalensi penderita gangguan ginjal semakin meningkat dari tahun ke tahun. Kompas.com menyajikan berita terkait data penderita penyakit ginjal pada tahun 2020 meningkat dua kali lipat dibanding tahun 2013[1]. Penderita penyakit ginjal kronik diperkirakan sekitar $10 \%$ dari penduduk dunia. Prevalensi penderita penyakit ginjal kronis berdasarkan Riskedas 2018 di Indonesia sebanyak 3,8 permil meningkat hampir 2 kali lipat dari tahun 2013 yang sebanyak 2 permil penderita [2]. Padmawati, et al (2018) [3] menyebutkan bahwa terdapat 717 pasien baru yang sedang menjalani hemodialisis pada tahun 2015 di Yogyakarta.

Tingkat prevalensi penyakit ginjal kronis yang tedapat di Indonesia mendorong penulis untuk melakukan penelitian diagnosis penyakit ginjal. Terdapat penelitian yang memanfaatkan sistem pakar dalam melakukan diagnosis penyakit ginjal kronis dengan gejala tertentu. Salah satunya yaitu Wahyuti, dkk (2018) yang melakukan penelitian untuk mendiagnosis awal penyakit ginjal pada manusia dengan merancang aplikasi sistem pakar berbasis android yang menggunakan metode forward chaining [4]. Tujuan penelitian ini adalah untuk mengetahui apakah seseorang yang mengalami penyakit ginjal kronis saat ini telah teridentifikasi beresiko sindrom metabolik sebelumnya.

\section{METODE PENELITIAN}

\subsection{Syndrom metabolik dan Gangguan ginjal}

Alberti dan Zimmet atas nama WHO menerangkan definisi sindrom metabolik dengan komponen-komponennya antara lain:

1. Gangguan pengaturan glukosa atau diabetes

2. Resistensi insulin

3. Hipertensi

4. Dislipidemia dengan trigliserida plasma $>150 \mathrm{mg} / \mathrm{dL}$ dan/atau kolesterol high density lipoprotein (HDL-C) 0,90; wanita: waist-to- hip ratio >0,8

5. Indeks massa tubuh (IMT) $>30 \mathrm{~kg} / \mathrm{m} 2$

6. Mikroalbuminuria (Urea Albumin Excretion Rate $>20 \mathrm{mg} / \mathrm{min}$ atau rasio lbumin/kreatinin $>30 \mathrm{mg} / \mathrm{g}$ ).

Sindrom metabolik dapat terjadi apabila salah satu dari 2 kriteria pertama dan 2 dari 4 kriteria terakhir terdapat pada individu tersebut, Jadi kriteria WHO 1999 menekankan pada adanya toleransi glukosa terganggu atau diabetes mellitus, dan atau resitensi insulin yang disertai sedikitnya 2 faktor risiko lainya itu hipertensi, dislipidemia, obesitas sentral dan mikroalbuminaria [5].

Kriteria yang sering digunakan untuk menilai pasien sindrom metabolik juga adalah dengan NCEP-ATP III, yaitu apabila seseorang memenuhi 3 dari 5 kriteria yang disepakati untuk orang asia, antara lain [6]:

1. Lingkar perut pria $\geq 90 \mathrm{~cm}$ atau wanita $\geq 80 \mathrm{~cm}$.

2. Hipertrigliseridemia (kadar serum trigliserida $\geq 150 \mathrm{mg} / \mathrm{dL}$ ).

3. Kadar HDL-C $\leq 40 \mathrm{mg} / \mathrm{dL}$ untuk pria atau $\leq 50 \mathrm{mg} / \mathrm{dL}$ untuk wanita.

4. Kadar glukosa darah puasa $\geq 110 \mathrm{mg} / \mathrm{dL}$.

5. Tekanan darah $\geq 130 / 85 \mathrm{mmHg}$.

Suatu kepastian fenomena klinis yang terjadi yaitu obesitas central menjadi indikator utama terjadinya sindrom metabolik sebagai dasar pertimbangan dikeluarkannya diagnosis terbaru oleh IDF tahun 2005 [6]. 
Fungsi ginjal yang menurun secara progresif yang terjadi selama beberapa bulan atau tahun merupakan tanda terjadinya gangguan pada ginjal. Penurunan fungsi ginjal tersebut ditandai dengan menurunnya Glomerular Filtration Rate (GFR) atau kadar filtrasi glomerulus yang lebih kecil dari $60 \mathrm{~mL} / \mathrm{min} / 1,73 \mathrm{~m} 2$ selama 3 bulan. Penurunan fungsi ginjal tersebut juga mengakibatkan terdapat kelainan pada darah, urin atau studi pencitraan yang menunjukkan kerusakan pada organ ginjal. Gangguan ginjal atau biasa disebut penyakit ginjal kronis sangat berdampak pada kesehatan tubuh [7].

Beberapa penyebab dari penyakit ginjal kronik di antaranya diabetes mellitus, hipertensi, glomerulonefritis kronis, nefritis intersisial kronis, penyakit ginjal polikistik, obstruksi, infeksi saluran kemih, obesitas dan ada yang tidak diketahui penyebabnya[7]. Merujuk pada penelitian sebelumnya, tingkat resiko gangguan ginjal dapat dipengaruhi oleh beberapa faktor, diantaranya adalah: kadar gula darah, kadar tekanan darah, kadar kolesterol, riwayat keluarga, dan pola hidup. Beberapa faktor tersebut di antaranya merupakan komponen sindrom metabolik di dalam tubuh [8]. Penelitian dari Ayu dkk, (2011) juga menjelaskan bahwa terdapat hubungan antara sindrom metabolik dengan prevalensi penyakit ginjal kronik yang menggunakan metode bivariate analisys [9].

\subsection{Sistem Inferensi Fuzzy}

Sistem inferensi fuzzy merupakan cabang pengetahuan dari sistem pakar. Konsep yang terdapat pada sistem pakar dalam penyelesaian masalah meniru layaknya seorang ahli. Pengetahuan ahli untuk memberikan solusi pada masalah tersebut menjadi dasar yang dimasukkan ke komputer yang biasa disebut black box atau kotak hitam [10].

Sistem inferensi fuzzy memberikan model keputusan dalam bentuk himpunan fuzzy dengan penalaran khusus. Himpunan fuzzy merupakan suatu himpunan dengan anggota yang bisa dibilang bias karena batasannya tidak jelas [11]. Terdapat tiga macam metode pada sistem inferensi fuzzy yaitu metode Madani, Tsukamoto dan Sugeno [12].

\subsection{Tahapan penelitian}

Langkah-langkah penelitian dilakukan agar dapat mengetahui gambaran dan rincian yang dibuat secara sistematis dan dapat dijadikan pedoman yang jelas dalam menyelesaikan permasalahan. Tahapan dalam penelitian ini antara lain: studi literatur penelitian sebelumnya, pengumpulan data, representasi kebutuhan (basis pengetahuaan), model inferensi sistem fuzzy, implementasi, dan pengujian.

Studi literatur pada penelitian ini mengumpulkan informasi penelitian yang membahas penyakit ginjal kronik yang disebabkan sindrom metabolik dan penelitian yang menggunakan metode Fuzzy dalam memberikan solusi untuk masalah tertentu. Pengumupulan data pada penelitian ini dibagi menjadi 2 bagian, yaitu data yang dipakai untuk pemodelan keputusan dan data rekam medis pasien yang akan digunakan untuk pengujian tingkat akurasi sistem.

Tahapan representasi kebutuhan terkait dengan basis pengetahuan yang berisi pengetahuan dan aturan tertentu dalam penyelesaian masalah. Pengetahuan direpresentasikan dengan menggunaan aturan berbentuk IF-THEN. Basis aturan akan dibuat pada setiap penyakit utama yang akan dilakukan identifikasi gejala penyertanya. Variabel yang akan digunakan untuk membangun model sistem inferensi antara lain index massa tubuh (IMT), hipertensi, High Density Lipoprotein (HDL) rendah, gula darah puasa (GDP) tinggi, trigliserid dan usia yang merupakan gejala sindrom metabolik tersebut yang menjadi faktor pada tingkat resiko gangguan ginjal [8]. 


\section{HASIL DAN PEMBAHASAN}

Pemodelan sistem pendukung keputusan untuk mengukur sindrom metabolik didasarkan pada beberapa variabel pendukung dengan himpunan yang menyertainya. Salah satu variabel yang menjadi ukuran untuk kemungkinan orang terkena sindrom metabolik adalah kadar trigliserida dalam tubuh. Himpunan kadar trigliserida tersebut berupa tinggi dan normal dengan nilai batas bawah $50 \mathrm{mg} / \mathrm{dl}$ dan batas atas $150 \mathrm{mg} / \mathrm{dl}$. Variabel dengan himpunan yang menyertainya untuk pengukuran sindrom metabolik ditampilkan pada tabel 1 .

Tabel 1. Variabel dan Himpunan Fuzzy Untuk Mengukur Sindrom Metabolik Sebagai Faktor Risiko pada Gangguan Ginjal [13].

\begin{tabular}{|l|l|l|c|c|l|}
\hline Kode & \multicolumn{1}{|c|}{ Variabel } & Himpunan & $\begin{array}{c}\text { Batas } \\
\text { bawah }\end{array}$ & $\begin{array}{c}\text { Batas } \\
\text { atas }\end{array}$ & $\begin{array}{c}\text { Keanggotaan } \\
\text { fungsi }\end{array}$ \\
\hline \multirow{2}{*}{$\mathrm{X}_{1}$} & \multirow{2}{*}{ Index Massa Tubuh $\left(\mathrm{kg} / \mathrm{m}^{2}\right)$} & Normal & 18,5 & 25 & Linear turun \\
\cline { 3 - 6 } & & Kegemukan & 18,5 & 25 & Linear naik \\
\hline \multirow{2}{*}{ X2 } & \multirow{2}{*}{ Trigliserida $(\mathrm{mg} / \mathrm{dl})$} & Normal & 50 & 150 & Linear turun \\
\cline { 3 - 7 } X3 & \multirow{2}{*}{ HDL pada laki-laki $(\mathrm{mg} / \mathrm{dl})$} & Tinggi & 50 & 150 & Linear naik \\
\cline { 3 - 7 } & \multirow{2}{*}{ HDL pada perempuan $(\mathrm{mg} / \mathrm{dl})$} & Normal & 40 & 50 & Linear turun \\
\cline { 3 - 7 } & & Normal & 50 & 60 & Linear naik \\
\hline \multirow{3}{*}{ X4 } & \multirow{2}{*}{ Tekanan darah sistolik $(\mathrm{mmHg})$} & Normal & 110 & 130 & Linear turun \\
\cline { 3 - 7 } & \multirow{2}{*}{ Tekanan darah sistolik $(\mathrm{mmHg})$} & Tinggi & 110 & 130 & Linear naik \\
\cline { 3 - 7 } & & Tormal & 80 & 85 & Linear turun \\
\hline \multirow{2}{*}{ X5 } & \multirow{2}{*}{ Gula darah puasa $(\mathrm{mg} / \mathrm{dl})$} & Normal & 80 & 85 & Linear naik \\
\cline { 3 - 7 } & & Tinggi & 80 & 110 & Linear turun \\
\hline
\end{tabular}

Berdasarkan variabel pada tabel 1, terdapat beberapa kriteria yang memberikan informasi bahwa orang akan beresiko terkena sindrom metabolik. Kriteria tersebut dibuat pada beberapa aturan untuk memberikan diagnosis awal orang dengan sindrom metabolik. Beberapa aturan yang dimaksud ditampilkan pada tabel 2 .

Tabel 2. Aturan Keputusan Diagnosis Sindrom Metabolik pada Penyandang PGK [13].

\begin{tabular}{|c|c|c|c|c|c|c|}
\hline \multirow{2}{*}{ Aturan } & \multicolumn{5}{|c|}{ Variabel } & \multirow{2}{*}{ Diagnosis Awal } \\
\cline { 2 - 6 } & IMT & Trigliserida & HDL & Tekanan darah & GDP & \\
\hline$[$ R1] & Kegemukan & Tinggi & Rendah & - & - & Beresiko \\
\hline$[$ R2] & Kegemukan & Tinggi & - & Tinggi & - & Beresiko \\
\hline$[$ R3] & Kegemukan & Tinggi & - & - & Tinggi & Beresiko \\
\hline$[R 4]$ & Kegemukan & - & Rendah & Tinggi & - & Beresiko \\
\hline$[$ R5] & Kegemukan & - & Rendah & - & Tinggi & Beresiko \\
\hline$[$ R6] & Kegemukan & - & - & Tinggi & Tinggi & Beresiko \\
\hline$[$ R7] & - & Tinggi & Rendah & Tinggi & - & Beresiko \\
\hline$[$ R8] & - & Tinggi & Rendah & - & Tinggi & Beresiko \\
\hline$[$ R9] & - & Tinggi & - & Tinggi & Tinggi & Beresiko \\
\hline$[R 10]$ & - & - & Rendah & Tinggi & Tinggi & Beresiko \\
\hline
\end{tabular}

Index massa tubuh (IMT) juga menjadi acuan apakah seseorang mengalami obesitas atau tidak selain dari ukuran lingkar pinggang. Perbedaannya ukuran IMT untuk menilai 
obesitas secara umum, sedangkan lingkar pinggang menilai obesitas abdominal. Hal tersebut menjadikan IMT sebagai salah satu indikator kemungkinan orang memiliki sindrom metabolik yang mengakibatkan penyakit ginjal kronik. Nilai IMT $\geq 25 \mathrm{~kg} / \mathrm{m} 2$ menandakan orang memiliki massa tubuh yang besar atau obesitas [14].

Fungsi keanggotaan pada linear turun variabel IMT adalah sebagai berikut:

$\mu_{\text {normal }}[a]=\left\{\begin{array}{cc}1, & a \leq 18,5 \\ \frac{25-a}{25-18,5}, & 18,5 \leq a \leq 25 \\ 0 & a \geq 25\end{array}\right.$

Fungsi keanggotaan pada linear naik variabel IMT adalah sebagai berikut:

$$
\mu_{\text {besar }}[a]=\left\{\begin{array}{cc}
0, & a \leq 18,5 \\
a-18,5 & 18,5 \leq a \leq 25 \\
25-18,5 & a \geq 25 \\
1 & a \geq 25
\end{array}\right.
$$

Berdasarkan tabel 1, diketahui trigliserida sebagai variabel penentu pada sindrom metabolik sebagai faktor risiko penyakit ginjal. Himpunan variabel trigliserida dikatakan tinggi apabila kadar trigliserida dalam tubuh mencapai lebih dari $150 \mathrm{mg} / \mathrm{dl}$. Kadar trigliserida dikatakan normal apabila kurang dari $150 \mathrm{mg} / \mathrm{dl}$.

Fungsi keanggotaan pada linear turun variabel trigliserida adalah sebagai berikut:

$\mu_{\text {normal }}[b]=\left\{\begin{array}{cc}1, & a \leq 50 \\ \frac{150-a}{150-50}, & 50 \leq a \leq 150 \\ 0 & a \geq 150\end{array}\right.$

Fungsi keanggotaan pada linear naik variabel trigliserida adalah sebagai berikut:

$\mu_{\text {tinggi }}[b]=\left\{\begin{array}{cc}0, & a \leq 50 \\ \frac{a-50}{150-50}, & 50 \leq a \leq 150 \\ 1 & a \geq 150\end{array}\right.$

Salah satu variabel dalam pengukuran tingkat resiko penyakit ginjal kronik yang berbeda pada laki-laki dan perempuan yaitu variabel High Density Lipoprotein (HDL). Fungsi keanggotaan pada linear turun variabel HDL pada laki-laki adalah sebagai berikut:

$\mu_{\text {rendah }}[c]=\left\{\begin{array}{cc}1, & a \leq 40 \\ \frac{a-40}{50-40}, & 40 \leq a \leq 50 \\ 0 & a \geq 50\end{array}\right.$

Fungsi keanggotaan pada linear naik variabel HDL pada laki-laki adalah sebagai berikut:

$\mu_{\text {normal }}[c]=\left\{\begin{array}{cc}0, & a \leq 40 \\ \frac{50-a}{50-40}, & 40 \leq a \leq 50 \\ 1 & a \geq 50\end{array}\right.$

Variabel HDL pada perempuan memiliki nilai normal apabila kadarnya di dalam tubuh lebih dari $60 \mathrm{mg} / \mathrm{dl}$. Fungsi keanggotaan pada linear turun variabel HDL pada perempuan adalah sebagai berikut:

$\mu_{\text {rendah }}[c]=\left\{\begin{array}{cc}1, & a \leq 50 \\ \frac{a-50}{60-50}, & 50 \leq a \leq 60 \\ 0 & a \geq 60\end{array}\right.$

Muhammad, et., al [Sistem Inferensi Fuzzy Untuk Prediksi Sindrom Metabolik Bagi Penyandang Penyakit Ginjal Kronik] 

berikut:

Fungsi keanggotaan pada linear naik variabel HDL pada perempuan adalah sebagai

$$
\mu_{\text {normal }}[c]=\left\{\begin{array}{cc}
0, & a \leq 50 \\
\frac{60-a}{60-50}, & 50 \leq a \leq 60 \\
1 & a \geq 50
\end{array} 6\right.
$$

Tekanan darah juga merupakan faktor resiko pada penyakit ginjal kronik dari gejala sindrom metabolik. Ukuran pada tekanan darah dikatakan tinggi apabila nilainya lebih dari 130/85 mm/Hg. Fungsi keanggotaan pada linear turun variabel tekanan darah sistolik adalah sebagai berikut:

$$
\mu_{\text {normal }}[d]=\left\{\begin{array}{cc}
1, & a \leq 110 \\
\frac{130-a}{130-110}, & 110 \leq a \leq 130 \\
0 & a \geq 130
\end{array}\right.
$$
berikut:

Fungsi keanggotaan pada linear naik variabel tekanan darah sistolik adalah sebagai $\mu_{\text {ting } g i}[d]=\left\{\begin{array}{cc}0, & a \leq 110 \\ \frac{a-110}{130-110}, & 110 \leq a \leq 130 \\ 1 & a \geq 130\end{array}\right.$

Fungsi keanggotaan pada linear turun variabel tekanan darah diastolik adalah sebagai berikut:

$\mu_{\text {normal }}[d]=\left\{\begin{array}{cc}1, & a \leq 80 \\ \frac{85-a}{85-80}, & 80 \leq a \leq 85 \\ 0 & a \geq 85\end{array}\right.$

Fungsi keanggotaan pada linear naik variabel tekanan darah diastolik adalah sebagai berikut:

$\mu_{\text {ting }{ }_{i}}[d]=\left\{\begin{array}{cc}0, & a \leq 80 \\ \frac{a-80}{85-80}, & 80 \leq a \leq 85 \\ 1 & a \geq 85\end{array}\right.$

Variabel kelima berdasarkan tabel 1 pada gejala sindrom metabolik yang berisiko terkena penyakit ginjal kronik yaitu gula darah puasa (GDP). Fungsi keanggotaan pada linear naik variabel GDP adalah sebagai berikut:

$\mu_{\text {normal }}[e]=\left\{\begin{array}{cc}1, & a \leq 80 \\ \frac{110-a}{110-80}, & 80 \leq a \leq 110 \\ 0 & a \geq 110\end{array}\right.$

Fungsi keanggotaan pada linear naik variabel GDP adalah sebagai berikut:

$\mu_{\text {tinggi }}[e]=\left\{\begin{array}{cc}0, & a \leq 80 \\ \frac{a-80}{110-80}, & 80 \leq a \leq 110 \\ 1 & a \geq 110\end{array}\right.$ 
Hasil diagnosis sistem inferensi fuzzy untuk memprediksi sindrom metabolik pada penderita penyakit ginjal kronik berupa persentase dari perhitungan melalui metode Fuzzy Tsukamoto. Nilai hasil diagnosis tersebut berada di antara 0-1. Tampilan grafik dalam derajad keanggotaan seperti pada gambar 13.

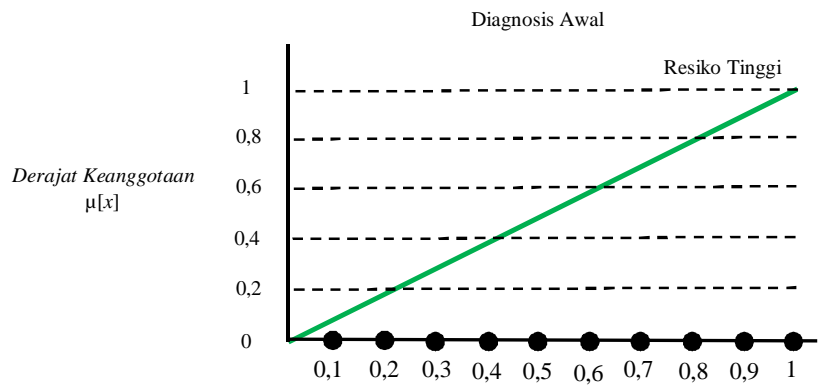

Gambar 2. Kurva Variabel Himpunan Fuzzy Variabel Kadar Output diagnosis

$\mu_{\text {Resiko Ting } i}[x]=\left\{\begin{array}{cc}1, & x \leq 0 \\ \frac{x-1}{1-0}, & 0 \leq x \leq 1 \\ 0 & x \geq 1\end{array}\right.$

Implementasi pengujian sistem fuzzy untuk pengukuran tingkat resiko sindrom metabolik menggunakan data pasien dengan PGK pada salah satu rumah sakit di Sleman. Terdapat 7 data pasein dengan penyakit ginjal kronik sebagai berikut:

Tabel 3. Data Pasien Dengan Penyakit Ginjal Kronik.

\begin{tabular}{|c|c|c|c|c|c|c|c|c|}
\hline $\begin{array}{c}\text { Pasien } \\
\text { ke- }\end{array}$ & $\begin{array}{c}\text { Jenis } \\
\text { kelamin }\end{array}$ & $\begin{array}{c}\text { Usia } \\
(\text { tahun })\end{array}$ & $\begin{array}{c}\text { Tinggi } \\
(\mathrm{cm})\end{array}$ & $\begin{array}{c}\text { Berat } \\
\text { badan } \\
(\mathrm{kg})\end{array}$ & $\begin{array}{c}\text { HDL } \\
(\mathrm{mg} / \mathrm{dL})\end{array}$ & $\begin{array}{c}\text { Trigli- } \\
\text { serida } \\
(\mathrm{mg} / \mathrm{dL})\end{array}$ & $\begin{array}{c}\text { Tekanan } \\
\text { darah } \\
(\mathrm{mmHg})\end{array}$ & $\begin{array}{c}\text { GDP } \\
(\mathrm{mg} / \mathrm{dL})\end{array}$ \\
\hline 1 & $\mathrm{~L}$ & 64 & 160 & 49 & 49,8 & 209 & $128 / 80$ & 132 \\
\hline 2 & $\mathrm{P}$ & 67 & 145 & 42 & 78,3 & 95,14 & $140 / 90$ & 102 \\
\hline 3 & $\mathrm{P}$ & 69 & 147 & 45 & 66,8 & 117 & $100 / 70$ & 103 \\
\hline 4 & $\mathrm{~L}$ & 56 & 168 & 53 & 31,2 & 177 & $130 / 90$ & 83 \\
\hline 5 & $\mathrm{~L}$ & 66 & 162 & 59 & 35 & 163,7 & $128 / 69$ & 90 \\
\hline 6 & $\mathrm{~L}$ & 67 & 162 & 51 & 32 & 275,3 & $160 / 87$ & 104 \\
\hline 7 & $\mathrm{~L}$ & 75 & 155 & 48 & 31 & 290,1 & $100 / 50$ & 190 \\
\hline
\end{tabular}

Pengujian diagnosis sindrom metabolik yang dialami berdasarkan variabel yang telah diketahui pertama kali dilakukan proses fuzzyfikasi pada masing-masing variabel. Nilai keanggotaan untuk setiap himpunan fuzzy diperoleh dengan menggunakan persamaan (1) sampai (14):

Kemudian $a_{\text {predikat }}$ untuk setiap aturan dihitung dengan cara mencari nilai minimal dari nilai keanggotaan himpunan pada variabel input. Sebagai contoh untuk data pertama pada tabel 3 nilai $a_{\text {predikat }}$ dapat dihitung sebagai berikut:

[R1] IMT kegemukan dan Trigliserida tinggi dan HDL rendah maka diagnosis awal beresiko

$$
\begin{aligned}
a_{\text {predikat } 1}= & \min (0,077 ; 0,02 ; 1) \\
& =0,02
\end{aligned}
$$

[R2] IMT kegemukan dan Trigliserida tinggi dan Tekanan darah tinggi maka diagnosis awal beresiko

$$
\begin{aligned}
a_{\text {predikat } 2} & =\min (0,077 ; 1 ; 0,9) \\
& =0,077
\end{aligned}
$$

Muhammad, et., al [Sistem Inferensi Fuzzy Untuk Prediksi Sindrom Metabolik Bagi Penyandang Penyakit Ginjal Kronik] 
[R3] IMT kegemukan dan Trigliserida tinggi dan GDP tinggi maka diagnosis awal beresiko

$$
\begin{aligned}
a_{\text {predikat } 3} & =\min (0,077 ; 1 ; 1) \\
& =0,077
\end{aligned}
$$

[R4] IMT kegemukan dan HDL rendah dan Tekanan darah tinggi maka diagnosis awal beresiko

$$
\begin{aligned}
a_{\text {predikat } 4}= & \min (0,077 ; 0,02 ; 0,9) \\
& =0,02
\end{aligned}
$$

[R5] IMT kegemukan dan HDL Rendah dan GDP tinggi maka diagnosis awal beresiko

$$
\begin{aligned}
a_{\text {predikat } 5} & =\min (0,077 ; 0,02 ; 1) \\
& =0,002
\end{aligned}
$$

[R6] IMT kegemukan dan Tekanan darah tinggi dan GDP tinggi maka diagnosis awal beresiko

$$
\begin{aligned}
a_{\text {predikat } 6} & =\min (0,077 ; 0,9 ; 1) \\
& =0,077
\end{aligned}
$$

[R7] Trigliserida tinggi dan HDL rendah dan Tekanan darah tinggi maka diagnosis awal beresiko

$$
\begin{aligned}
a_{\text {predikat } 7}= & \min (0,077 ; 0,02 ; 0,9) \\
& =0,002
\end{aligned}
$$

[R8] Trigliserida tinggi dan HDL rendah dan GDP tinggi maka diagnosis awal beresiko

$$
\begin{aligned}
a_{\text {predikat } 8} & =\min (1 ; 0,02 ; 1) \\
& =0,02
\end{aligned}
$$

[R9] Trigliserida tinggi dan Tekanan darah tinggi dan GDP tinggi maka diagnosis awal beresiko

$$
\begin{aligned}
a_{\text {predikat } 9} & =\min (1 ; 0,9 ; 1) \\
& =0,9
\end{aligned}
$$

[R10] HDL rendah dan Tekanan darah tinggi dan GDP tinggi maka diagnosis awal beresiko

$$
\begin{aligned}
a_{\text {predikat } 10} & =\min (0,02 ; 0,9 ; 1) \\
& =0,02
\end{aligned}
$$

Setelah diketahui nilai $a$ dari setiap aturan, maka nilai fuzzy terakit tingkat resiko sindrom metabolik merupakan nilai maksimal antara semua nilai a yang diperoleh dari semua aturan.

$$
\begin{gathered}
Z=\max \left(a_{\text {predikat } 1}, a_{\text {predikat } 2}, a_{\text {predikat } 3}, \ldots a_{\text {predikat } 10}\right) \\
Z=0,9 \\
\text { persentase }=0,9 \times 100 \%=90 \%
\end{gathered}
$$

Persentase kemungkinan pasien 1 terdiagnosis sindrom metabolik adalah $90 \%$.

Hasil pengujian sistem inferensi fuzzy yang dibangun berbasis web untuk diagnosis sindrom metabolik untuk 7 data pasien penyakit ginjal kronik adalah sebagai berikut:

Tabel 4. Hasil Diagnosis Sindrom Metabolik pada Pasien Penyakit Ginjal Kronik pada Sistem Fuzzy yang Dibuat Berbasis Web

\begin{tabular}{|c|c|c|c|c|c|l|}
\hline Pasien ke- & $\begin{array}{c}\text { Indeks Massa } \\
\text { tubuh }\left(\mathrm{kg} / \mathrm{m}^{2}\right)\end{array}$ & $\begin{array}{c}\mathrm{HDL} \\
(\mathrm{mg} / \mathrm{dL})\end{array}$ & $\begin{array}{c}\text { Trigliserida } \\
(\mathrm{mg} / \mathrm{dL})\end{array}$ & $\begin{array}{c}\text { Tekanan darah } \\
(\mathrm{mmHg})\end{array}$ & $\begin{array}{c}\text { GDP } \\
(\mathrm{mg} / \mathrm{dL})\end{array}$ & Hasil diagnosis \\
\hline 1 & 19 & 49,8 & 209 & $128 / 80$ & 132 & $90 \%$ beresiko \\
\hline 2 & 20 & 78,3 & 95,14 & $140 / 90$ & 102 & $45 \%$ beresiko \\
\hline 3 & 21 & 66,8 & 117 & $100 / 70$ & 103 & $38 \%$ beresiko \\
\hline 4 & 19 & 31,2 & 177 & $130 / 90$ & 83 & $100 \%$ beresiko \\
\hline 5 & 22 & 35 & 163,7 & $128 / 69$ & 90 & $90 \%$ beresiko \\
\hline 6 & 19 & 32 & 275,3 & $160 / 87$ & 104 & $100 \%$ beresiko \\
\hline 7 & 20 & 31 & 290,1 & $100 / 50$ & 190 & $100 \%$ beresiko \\
\hline
\end{tabular}


Dari tujuh data pada tabel 4 tersebut diperoleh hasil bahwa ada 7 pasien yang telah teridentifikasi berisiko sindrom metabolik. Hal ini menunjukkan bahwa seseorang yang mengalami penyakit ginjal kronis sangat dimungkinkan sebelumnya telah teridentifikasi sindrom metabolik. Oleh karena itu, pengukuran tingkat risiko sindrom metabolik sangat dibutuhkan sedini mungkin agar dapat dilakukan tindakan pencegahan terjadinya komplikasi lebih lanjut.

\section{KESIMPULAN}

Kesimpulan yang diapat diambil dari penelitian ini adalah:

1. Sistem inferensi fuzzy dapat digunakan untuk memprediksi tingkat risiko sindrom metabolik terutama untuk gejala-gejala yang mendekati batas normal pengukuran klinis.

2. Hasil prediksi tingkat risiko tersebut berhubungan dengan terjadinya komplikasi penyakit ginjal kronis.

\section{SARAN}

Untuk penelitian selanjutnya, disarankan untuk menggunakan variabel yang lebih mendukung seperti ukuran lingkar perut.

\section{DAFTAR PUSTAKA}

[1] E. Pranita, 2020, "Penyakit Ginjal di Indonesia Meningkat 2 Kali Lipat, Bisakah Dicegah?,” kompas.com.

[2] Kemenkes RI. 2018, Hasil Utama Riset Kesehata Dasar (RISKESDAS).

[3] R. S. Padmawati, Y. W. Subronto, and B. S. Zega, 2018. "Edukasi Kesehatan Bagi Pasien Penderita Gagal Ginjal Kronis yang Menjalani Terapy Hemodialisis di RSUP Dr Sarjito Yogyakarta,"

[4] W. Wahyuti, I. Permana, and F. N. Salisah, 2018. "Aplikasi Sistem Pakar Berbasis Android Untuk Diagnosa Awal Penyakit Ginjal Manusia Menggunakan Metode Forward Chaining," Sntiki, Vol. 10, No. November, pp. 121-128.

[5] WHO, 1999. "Definition, Diagnosis and Classification of Diabetes Mellitus and Its Complications: Report of A WHO Consultation. Part 1, Diagnosis and Classification of Diabetes Mellitus, "World Health Organization.

[6] S. Rini, 2015, “Sindrom Metabolik,” Jan.

[7] Depkes RI, 2017, "Infodatin Pusat Data dan Informasi Kementerian Kesehatan RI: Situasi Penyakit Ginjal Kronis,"

[8] K. Ikawati, S. Chasani, S. Suhartono, S. Hadisaputro, and S. Budijitno, 2018, "Komponen Sindrom Metabolik sebagai Faktor Risiko Penyakit Ginjal Kronik Stadium Terminal (Studi di RSUP Dr.Kariadi dan RSUD Kota Semarang)," Jurnal Epidemiologi Kesehatan 
Komunitas, Vol. 3, No. 1, p. 18.

[9] P. Ayu, Y. Kandarini, G. Widiana, W. Sudhana, J. Loekman, and K. Suwitra, 2011 "Prevalensi dan Hubungan Sindrom Metabolik Dengan Penyakit Ginjal Kronik pada Populasi Desa Legian, Kuta Bali,” Journal of Internal Medicine, Vol. 12, No. 2.

[10] S. Kusumadewi, 2003, Artificial Intelligence (Teknik dan Aplikasinya). Graha Media, Yogyakarta.

[11] H. Nasution, 2012, "Implementasi Logika Fuzzy pada Sistem Kecerdasan Buatan," Jurnal ELKHA, Vol. 4, No. 2,.

[12] N. F. Susanto, 2016. "Deteksi Dini Penyakit Demam Berdarah Dengan Metode Fuzzy Expert System.” Universitas Islam Negeri Maulana Malik Ibrahim,

[13] S. Kusumadewi, L. Rosita, and E. G. Wahyuni, 2020, Model Sistem Pendukung Keputusan Klinis Untuk Sindrom Metabolik, UII Press, Yogyakarta.

[14] E. E et al., 2015. "Pedoman Tatalaksana Dislipidemia PERKI 2013," Indonesian Journal of Cardiology, pp. 245-70, Apr. 